\title{
PERFORMANCE OF PRECAST ANAEROBIC DIGESTION TANK COMBINED WITH A FOOD WASTE DISPOSER SYSTEM. A CASE STUDY OF HOUSEHOLD FOOD WASTE IN THAILAND
}

\begin{abstract}
The actual sizes of precast anaerobic digestion tanks $\left(600 \mathrm{dm}^{3}\right)$ combined with food waste disposer systems (PAD-FWD) were selected to investigate efficiency under actual use conditions. The effects of organic loading rates (OLRs) and the presence of linear alkylbenzene sulfonate (LAS) surfactants in dishwashing liquid on the organic removal efficiency and biogas generation of PAD-FWD were studied. According to the findings, the PAD-FWD at an OLR of $0.13 \mathrm{~kg} \mathrm{VS} /\left(\mathrm{m}^{3} \cdot\right.$ day $)$ and hydraulic retention time (HRT) of 12 days could be applied to treat food waste without adding any nutrients to the system to effectively produce biogas. Under operating conditions of the LAS concentration of $63.4 \mathrm{mg} / \mathrm{dm}^{3}$, PAD-FWD was able to reach a steady-state condition with a performance similar to the system without added LAS. The quality of effluent from the PAD-FWD system was unable to meet the effluent standard for households; thus, this effluent should be collected for treatment in a secondary wastewater treatment plant (WTP) before release into the environment. The effluent quality at an OLR of $0.13 \mathrm{~kg} \mathrm{VS} /\left(\mathrm{m}^{3} \cdot\right.$ day) was in the range of the influent properties of the central WTP, which ensures that the pollutants in the effluent do not increase the overall burden on the WTP. The bio-sludge from PAD-FWD was not a sufficient nutrient source for the growing plants. However, the germination index (GI) of the effluent at an OLR of $0.13 \mathrm{~kg} \mathrm{VS} /\left(\mathrm{m}^{3}\right.$.day) did meet the fertilizer standard. The results of this study can be applied to develop self-management of food waste technology to encourage the separation of food waste at the origin within households.
\end{abstract}

\section{INTRODUCTION}

Currently, most of the food waste from households in Thailand is disposed into landfills, and the food waste is always left out and not separated from other solid wastes.

${ }^{1}$ National Metal and Materials Technology Center, 114 Pathumthani, Thailand.

${ }^{2}$ Department of Environmental Engineering, Faculty of Engineering, Chulalongkorn University, Bangkok 10330, Thailand.

${ }^{3}$ Research Unit of Environmental Mangement and Sustainable Industry, Faculty of Engineering, Chulalongkorn University, Bangkok, 10330 Thailand, corresponding author, e-mail address: Orathai.C@chula.ac.th 
As a consequence, the recycling of household waste is more difficult. Moreover, food waste is an organic matter that can rot and be malodorous with an impact on the health of people living around landfill areas as a source of infection. In addition, landfill areas are limited due to urban expansion while the amount of municipal solid wastes (MSW) increases every year. In 2012, the amount of MSW in Bangkok was 8000-9000 t/day with a high percentage of food waste at $63.3 \%$ [1]. Food waste comprises mainly carbohydrates, starches, dietary fiber, proteins, lipids and salt. Landfill disposal of this waste may give rise to leachate production and further air and soil pollution. Furthermore, the decomposition of food waste in landfills by anaerobic bacteria results in the release of the harmful greenhouse gas (GHG) methane, which also exacerbates the problem of climate change. One alternative solution for dealing with this food waste problem is the encouragement of technology for the self-management of food waste in households, which can reduce the amount of food waste going to landfills. Anaerobic digestion (AD) is a waste-treatment and renewable-energy technology for wastewater and solid organic waste streams. Recently, AD has been recognized as one of the best options for treating the food waste fraction of MSW because it results in two valuable final products, biogas and compost, which may be utilized for electricity production and as soil fertilizer, respectively. $\mathrm{AD}$ has been recognized to be superior to landfilling and aerobic composting $[2,3]$. AD is the consequence of a series of metabolic interactions among various groups of microorganisms. It occurs in four stages involving the production of methane using the anaerobic digestion process. One group of microorganisms secretes enzymes that hydrolyze polymeric materials into monomers such as glucose and amino acids. Then, the soluble organic matter and the products of hydrolysis are converted into organic acids, alcohols, hydrogen and carbon dioxide by acidogenic bacteria. Third, acetogenic bacteria convert the products of the acidiogens into acetic acid, hydrogen and carbon dioxide. Finally, methanogenic bacteria are responsible for methane production from the acetogen products.

The main advantage in using anaerobic digestion is the biogas production which can be used for steam heating, cooking and generation of electricity [4]. The organic loading has been suggested to be $0.5-1.6 \mathrm{~kg} /\left(\mathrm{m}^{3} \cdot\right.$ day) of volatile solids (VS) for a standard-rate digester and $1.6-4.8 \mathrm{~kg} /\left(\mathrm{m}^{3} \cdot\right.$ day $)$ of VS for a high-rate digester. The optimal $\mathrm{pH}$ digestion was between 6.8 and 7.3 [5]. The primary challenge of AD technology is the economic feasibility in terms of capital investment, operating costs, and revenues from the biogas and compost product.

A food waste disposer is a device that is usually installed under a kitchen sink between the sink's drain and the trap, which shreds food waste into pieces small enough to pass through plumbing [6]. Next, these small pieces of food waste are mixed with wastewater to become food wastewater and flow through plumbing via a precast anaerobic digestion tank that is usually installed in most Thai households by law for the preliminary treatment of food wastewater before release into public drainage. In this research, a precast anaerobic digestion tank combined with a food waste disposer system 
(PAD-FWD system), a technology for the self-management of food waste in households, was selected to study the application for food waste disposal through anaerobic digestion for biogas production. The PAD-FWD system should help separate and treat food waste at its origin within households and also obtain byproducts in the form of compost and biogas. In Thailand, this technology has not been studied in terms of efficiency and application on an actual scale for treating food wastewater from households. Thus, this research aims to find the capacity for the disposal of food waste by a PAD-FWD system under actual-use conditions by using a practically sized $\left(600 \mathrm{dm}^{3}\right)$ precast anaerobic septic tank sold on the market. Moreover, the effects of the organic loading rate (OLR) and the surfactant in dishwashing liquid on the organic removal efficiency and biogas generation of the PAD-FWD system were studied to imitate the conditions of actual use. The results of this study could be applied to design PAD-FWD systems as an option in food waste management by households in Thailand.

\section{MATERIALS AND METHODS}

Precast anaerobic digestion tank combined with food waste disposer. The PAD-FWD system in this research comprised two parts: a food waste grinder and a precast anaerobic septic tank. The food waste grinder was installed directly with a drainage tube under the sink to grind food waste small enough to flow into the drainpipe with wastewater. A commercial food waste grinder under the Franke brand was selected for this experiment. The power of the grinder's was $370 \mathrm{~W}$ with a capacity for grinding $1 \mathrm{~kg}$ of food waste within $1 \mathrm{~min}$. For the second part, a commercial-sized precast anaerobic septic tank under the Cotto brand used to treat food wastewater from the food waste grinder was selected for this experiment.

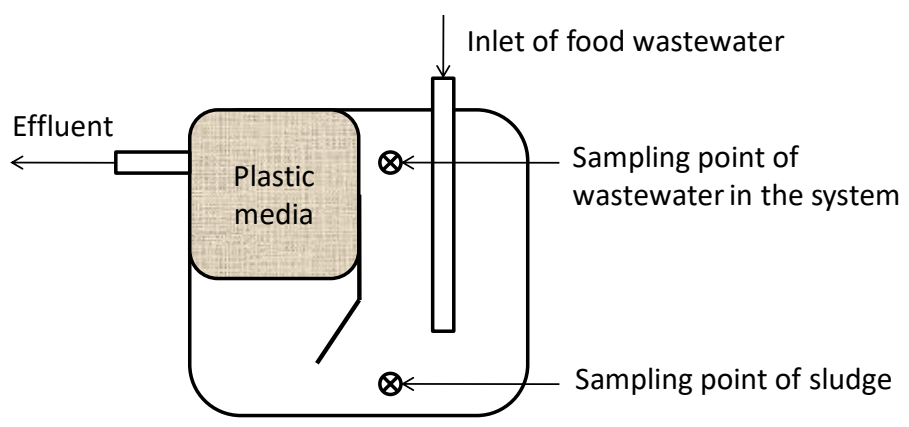

Fig. 1. Sampling point of precast anaerobic septic tank

The volume of the tank was $600 \mathrm{dm}^{3}$, and it had a round shape with a diameter of $110 \mathrm{~cm}$ and a height of $117 \mathrm{~cm}$. The precast anaerobic septic tank was divided into two chambers by a baffle. The first chamber directly served food wastewater into anaerobic 
digestion condition, and the second chamber filtered the food wastewater treated in the first chamber. Fifty plastic media were imbedded in the second chamber to reduce the removal of sludge from the system and increase the contact area between anaerobic microbes and food wastewater. The sampling points of the PAD reactor were connected to a $5 \mathrm{~cm}$ in diameter PVC tube at the inlet to feed the food wastewater into the system with faucets installed at the middle, bottom and outlet of the septic tank to collect the wastewater and sludge from the system as shown in Fig. 1.

Food waste feedstock. Food waste was collected from the cafeteria at Chulalongkorn University, Bangkok. The food waste was composed of food preparation waste and leftover meals. After large bones were removed, the food waste was mixed and fed into a grinder with water (food waste: tap water ratio $=1: 1$ by weight or $1 \mathrm{~kg}$ food waste: $1 \mathrm{dm}^{3}$ water) for transformation into food wastewater. The size of the ground food waste was approximately $0.5-2 \mathrm{~cm}$. The food wastewater was separated into three layers. The top layer comprised vegetable scraps and fat floating on the surface; the middle was the water layer, and the bottom layer comprised rice and meat scraps. The food wastewater was diluted with tap water to meet the OLR of $0.42,0.21$ and $0.13 \mathrm{~kg} \mathrm{VS} /\left(\mathrm{m}^{3} \cdot\right.$ day) (or equal to food waste of $1 \mathrm{~kg} / 50 \mathrm{dm}^{3}, 0.5 \mathrm{~kg} / 50 \mathrm{dm}^{3}$ and $0.3 \mathrm{~kg} / 50 \mathrm{dm}^{3}$ ) before being fed into the reactor. Table 1 shows the characteristics of the food wastewater feedstock at various OLRs.

Table 1

Chemical properties of food wastewater at various organic loading rate

\begin{tabular}{|l|c|c|c|c|c|c|}
\hline \multirow{3}{*}{ Parameter } & \multicolumn{6}{|c|}{ OLR $\left[\mathrm{kg} \mathrm{VS} /\left(\mathrm{m}^{3} \cdot\right.\right.$ day $\left.)\right]$} \\
\cline { 2 - 7 } & \multicolumn{2}{|c|}{0.42} & \multicolumn{2}{c|}{0.21} & \multicolumn{2}{c|}{0.13} \\
\cline { 2 - 7 } & Min-Max & Avg. & Min-Max & Avg. & Min-Max & Avg. \\
\hline $\mathrm{COD}, \mathrm{mgO}_{2} / \mathrm{dm}^{3}$ & $4,880-5,310$ & 5,188 & $2,330-2,738$ & 2,498 & $1,355-1,710$ & 1,525 \\
\hline $\mathrm{TS}, \mathrm{mg} / \mathrm{dm}^{3}$ & $6,070-6,255$ & 6,162 & $1,880-2,280$ & 2,060 & $1,585-1310$ & 1,478 \\
\hline $\mathrm{VS}, \mathrm{mg} / \mathrm{dm}^{3}$ & $5,925-6,140$ & 6,032 & $1,650-2,200$ & 1,918 & $1,230-1,495$ & 1,388 \\
\hline $\mathrm{pH}$ & $6.35-6.54$ & 6.44 & $6.35-6.67$ & 6.53 & $6.39-6.71$ & 6.55 \\
\hline $\mathrm{TKN}, \mathrm{mg} / \mathrm{dm}^{3}$ & $29.10-40.70$ & 35.1 & $20.70-25.50$ & 23.1 & $16.90-20.30$ & 18.6 \\
\hline $\mathrm{TP}, \mathrm{mg} / \mathrm{dm}^{3}$ & $3.25-4.02$ & 3.48 & $2.01-2.60$ & 2.26 & $1.53-1.92$ & 1.65 \\
\hline $\mathrm{O} \& \mathrm{G}, \mathrm{mg} / \mathrm{dm}^{3}$ & - & 470 & - & 350 & - & 297 \\
\hline
\end{tabular}

COD - chemical oxygen demand, TS - total solid, VS - volatile solid, TKN - total Kjeldahl nitrogen, $\mathrm{TP}$ - total phosphorus, O\&G - oil and grease.

Experimental conditions. During the start-up phase, the PAD reactor was fed with food wastewater at an OLR of $0.42 \mathrm{~kg} \mathrm{VS} /\left(\mathrm{m}^{3} \cdot\right.$ day) and hydraulic retention time (HRT) of 45 days for 2 months for microbial acclimation. Subsequently, the PAD reactor was fed with the food wastewater at the OLR of $0.42 \mathrm{~kg} \mathrm{VS} /\left(\mathrm{m}^{3}\right.$.day) with the HRT of 12 days. The food wastewater was fed once a day. The reactor was operated continuously for 27 days. Steady-state conditions were achieved within 28 days after the start-up. 
The steady state was marked by relatively stable soluble COD concentrations in the effluent varying by less than 5\%. The reactor was run for another 28-37 days under the existing loading conditions. Later, the reactor was fed with the lower-strength food wastewater to obtain a test OLR of $0.21 \mathrm{~kg} \mathrm{VS} /\left(\mathrm{m}^{3} \cdot\right.$ day $)$ and $0.13 \mathrm{~kg} \mathrm{VS} /\left(\mathrm{m}^{3} \cdot\right.$ day $)$. Steady-state conditions were achieved within 13-23 days after initiating the new OLRs.

To study the effect of linear alkylbenzene sulfonate (LAS) surfactants on the PAD reactor performance, the food wastewater was mixed with dishwashing liquid at LAS concentrations of 63.4 and $252 \mathrm{mg} / \mathrm{dm}^{3}$. The reactor was operated continuously at an OLR of $0.13 \mathrm{~kg} \mathrm{VS} /\left(\mathrm{m}^{3} \cdot\right.$ day $)$ throughout the experiment.

Analytical methods. After the system reached a steady state, the wastewater in the septic tank, sludge and effluent were sampled and analyzed according to the parameters for checking the operation. Total volatile solids (VS), suspended solids (SS), total solids (TS), COD, BOD, oil and grease (O\&G), total Kjeldhal nitrogen (TKN), total phosphorus (TP), alkalinity (Alk), volatile fatty acid (VFA), and LAS concentration were determined using standard methods [7]. The fertilizer quality of the sludge and the effluent from the PAD-FWD system were evaluated in accordance with guidelines for the analysis of organic fertilizer [8] including the germination index (GI), organic matter (OM), $\mathrm{C} / \mathrm{N}$ ratio, electrical conductivity (EC), and content (\%) of N, $\mathrm{P}$ and $\mathrm{K}$. The biogas production volumes were recorded on a daily basis. The $\mathrm{CH}_{4}$ content in biogas was measured using a gas chromatograph (GC-TCD) Shimadzu GC-14B with a thermal conductivity detector and molecule sieve $13 x$ column. Under each experimental condition mentioned above, the pollutant removal efficiency (PRE) of the PAD-FWD system was calculated from the equation:

$$
\mathrm{PRE}=\frac{P_{\text {in }}-P_{\text {eff }}}{P_{\text {in }}} \times 100
$$

where $P_{\text {in }}$ and $P_{\text {eff }}$ are the pollution parameters such as COD, TS, VS, TKN, TP, O\&G of the food wastewater input and effluent into the system, respectively.

\section{RESULTS AND DISCUSSION}

\subsection{PROPERTIES OF THE PAD-FWD SYSTEM UNDER START-UP CONDITIONS}

The duration for operating the PAD-FWD system to reach a steady state under the start-up conditions was approximately 60 days. The steady COD of the wastewater in the anaerobic septic tank (CODsys) was found to range between 1654-2744 $\mathrm{mg} \mathrm{O}_{2} / \mathrm{dm}^{3}$, and the soluble COD (CODsys, sol) value was relatively low at $217 \mathrm{mg} \mathrm{O} / \mathrm{dm}^{3}$. The COD of the effluent from the anaerobic septic tank (CODeff) at $1394 \mathrm{mg} \mathrm{O} / \mathrm{dm}^{3}$ was 
less than approximately $35 \%$ of the CODsys, and its soluble COD (CODeff, sol) at $180 \mathrm{mg} \mathrm{O} / \mathrm{dm}^{3}$ was close to the CODsys, sol. The amount of biogas generation was approximately $137 \mathrm{dm}^{3} /$ day within a temperature range of $29-32{ }^{\circ} \mathrm{C}$. For the conditions within the system during the steady state, $\mathrm{pH}$ of the wastewater and effluent from the anaerobic septic tank (pHsys, pHeff) ranged between 6.74-6.94 and 7.02-7.15, respectively, which was suitable for the operation of the anaerobic microorganisms. The alkalinity of the wastewater in the system (Alksys) and the effluent (Alkeff) ranged between 1000 and $1100 \mathrm{mg} \mathrm{CaCO}_{3} / \mathrm{dm}^{3}$, which was lower than the alkalinity suitable for operating anaerobic microorganisms of $1500-2000 \mathrm{mg} \mathrm{CaCO} / \mathrm{dm}^{3}$. The volatile fatty acids of the system (VFAsys) were probably close to the VFA of the effluent (VFAeff) within a range of $60-65 \mathrm{mg} / \mathrm{dm}^{3}$ as acetic acid. The VFA/Alk ratio of the wastewater in the system and the effluent were similar with an average value below 0.1 . These data indicate that the anaerobic septic tank was a high-buffer system, which makes changing the $\mathrm{pH}$ difficult.

\subsection{EFFECTS OF OLRS ON PAD-FWD SYSTEM PERFORMANCE}

Figure 2 shows the COD of the feed and effluent from the reactor at various OLRs. The data show that the CODsys (the COD of wastewater in the anaerobic digestion compartment) and CODeff (the COD of effluent from the up-flow anaerobic filter compartment) decreased upon decreasing OLR. At OLRs of $0.42,0.21$ and $0.13 \mathrm{~kg} \mathrm{VS} /\left(\mathrm{m}^{3} \cdot \mathrm{day}\right)$, the average CODsys at the steady state was $1900,900,480 \mathrm{mg} \mathrm{O} / \mathrm{dm}^{3}$ and the average CODeff was $728,328,161 \mathrm{mg} \mathrm{O} / \mathrm{dm}^{3}$, respectively. The COD removal efficiency of the reactor increased slightly from $86 \%$ to $87 \%$ and $89 \%$, respectively. The anaerobic digestion port and the up-flow anaerobic filter port of the reactor were observed to remove COD at $64-74 \%$ and $85-89 \%$, respectively. The CODsys, sol and the CODeff, sol were likely similar throughout the experiment.

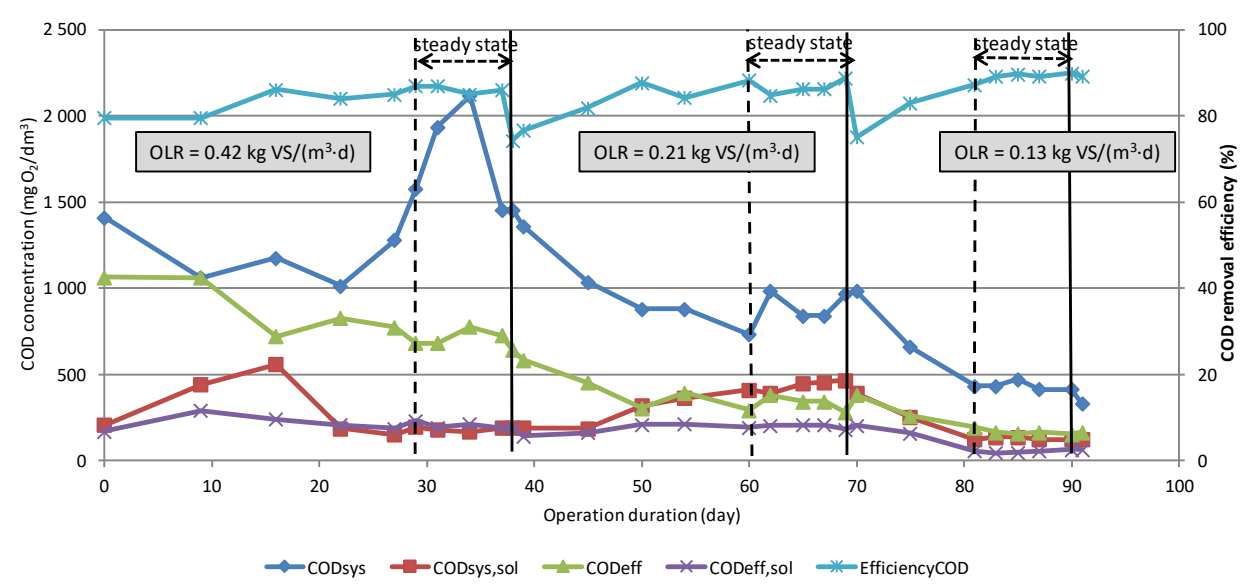

Fig. 2. COD concentration and COD removal efficiency of the PAD-FWD system under various OLR 
When the results are compared with similar systems, namely, the wastewater from tuna processing treated [9] at an OLR of $0.05 \mathrm{~kg} \mathrm{VS} /\left(\mathrm{m}^{3} \cdot\right.$ day) and the wastewater from blanching noodles treated at an OLR of $0.28 \mathrm{~kg} \mathrm{VS} /\left(\mathrm{m}^{3} \cdot\right.$ day $)$ [10], the COD removal efficiency of the PAD-FWD system was found to be similar in the both systems at 81.33 and $89.72 \%$, respectively. However, when considered in terms of the HRT, the HRT of the PAD-FWD system at 12 days was found to be shorter than of both systems at 30 days. Overall, the COD removal efficiency of the precast anaerobic septic tank in this research was found to be relatively high. In every OLR experiment, the COD removal efficiency was higher than $85 \%$ because there were factors that increased the system efficiency. One factor was the properties of the food wastewater put into the PAD-FWD system composed of noncomplex organic compounds and small particles ground to help the microbes decompose more quickly and efficiently. The other factor was the plastic media contained inside the anaerobic septic tank, which prevents the sludge from leaching out of the system and thoroughly exposes the sludge to the organic matter, thereby increasing the COD removal efficiency.

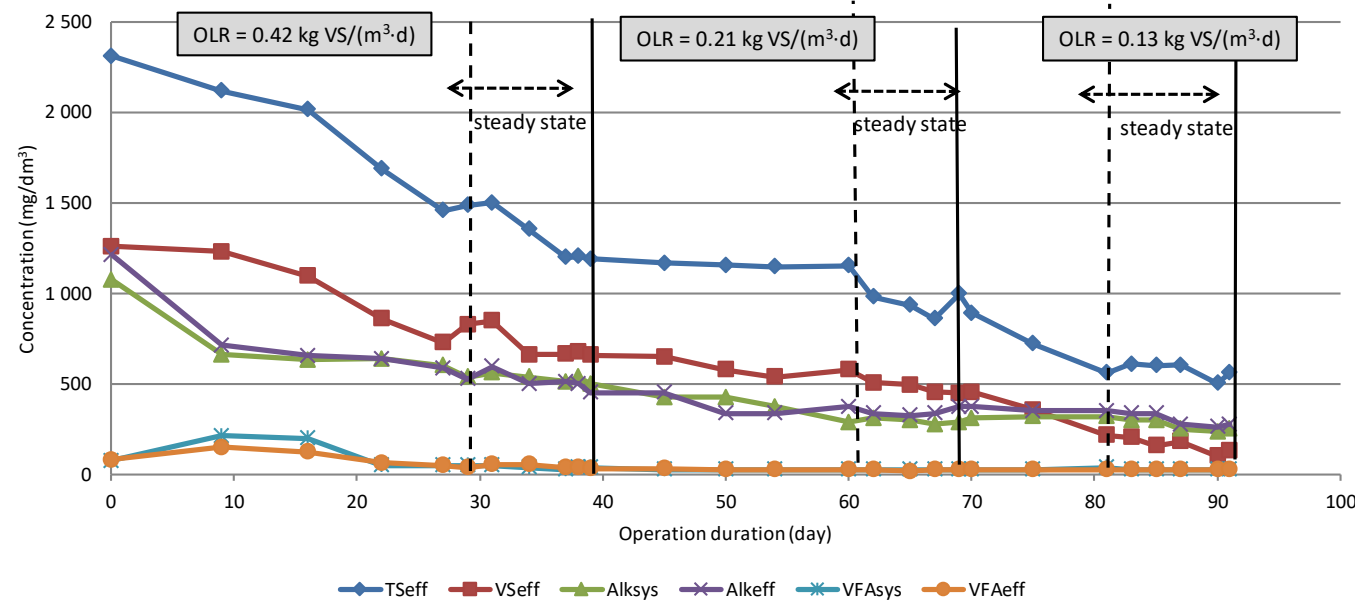

Fig. 3. TS, VS, VFA and Alk of PAD-FWD system under various OLR

Figure 3 shows the amount of total solids in the effluent from the septic tank (TSeff) at each OLR. The results show that the TSeff tended to decrease upon decreasing OLR. At an OLR of $0.42 \mathrm{~kg} \mathrm{VS} /\left(\mathrm{m}^{3} \cdot\right.$ day $)$, the amount of total solids leaching out from the system in the beginning phase was high because the HRT was changed from 45 days to 12 days. After 30 days of operation, the system generally reached a steady state with a decrease in total solids leaching out. At OLRs of $0.42,0.21$ and $0.13 \mathrm{~kg} \mathrm{VS} /\left(\mathrm{m}^{3} \cdot\right.$ day $)$, the average TSeff at steady state were 1398,989 and $575 \mathrm{mg} / \mathrm{dm}^{3}$ and the TS removal efficiency of the FWD system calculated by Eq. (1) were 77, 52 and $61 \%$, respectively. 
Figure 3 shows that at OLRs of $0.42,0.21$ and $0.13 \mathrm{~kg} \mathrm{VS} /\left(\mathrm{m}^{3} \cdot\right.$ day $)$, the average VSeff at steady state were 745,476 and $155 \mathrm{mg} / \mathrm{dm}^{3}$, respectively. Under various operating OLRs, the VS/TS ratio in the influent was found to be close within a range of 0.93-0.98, whereas the VS/TS ratio of the effluent was found to be within a range of 0.27-0.48 and tended to decrease upon decreasing OLR. This result shows that the PAD reactor had a high potential for decomposing food wastewater which resulted in a lower VS/TS ratio in the effluent with a VS removal efficiency of $75-89 \%$ throughout the experiment. Food waste feed contains easily biodegradable substrates for microorganisms, and it was ground into small pieces to increase the surface area for hydrolysis bacteria to convert polymers into monomers such as glucose amino acids and fatty acid. Consequently, these monomers were converted into volatile fatty acids and $\mathrm{CH}_{4}$ by acidogenic and methanogenic bacteria. Higher OLRs can cause incomplete hydrolysis, acidogenesis and methanogenesis in the first compartments, thus shifting the anaerobic digestion to the second compartments. Therefore, it can be concluded that the up-flow anaerobic filter compartment effectively removes organic matter and prevents bacterial erosion from the reactor.

Table 2

Average organic removal efficiency by the PAD-FWD system under various OLR

\begin{tabular}{|c|c|c|c|c|c|c|c|c|c|}
\hline $\begin{array}{c}\text { OLR } \\
{\left[\mathrm{kg} \mathrm{VS} /\left(\mathrm{m}^{3} \cdot \mathrm{day}\right)\right]}\end{array}$ & $\begin{array}{c}\mathrm{TKN} \text { in } \\
{\left[\mathrm{mg} / \mathrm{dm}^{3}\right]}\end{array}$ & $\begin{array}{c}\text { TKN }{ }_{\text {eff }} \\
{\left[\mathrm{mg} / \mathrm{dm}^{3}\right]}\end{array}$ & $\begin{array}{c}\text { EffTKN } \\
{[\%]}\end{array}$ & $\begin{array}{c}P_{\text {in }} \\
{\left[\mathrm{mg} / \mathrm{dm}^{3}\right]}\end{array}$ & $\begin{array}{c}P_{\text {eff }} \\
{\left[\mathrm{mg} / \mathrm{dm}^{3}\right]}\end{array}$ & $\begin{array}{c}\mathrm{Effp} \\
{[\%]}\end{array}$ & $\begin{array}{c}\text { O\&Gin } \\
{\left[\mathrm{mg} / \mathrm{dm}^{3}\right]}\end{array}$ & $\begin{array}{c}\text { O\&Geff } \\
{\left[\mathrm{mg} / \mathrm{dm}^{3}\right]}\end{array}$ & $\begin{array}{c}\text { Effo\&G } \\
{[\%]}\end{array}$ \\
\hline 0.42 & 35.1 & 66.66 & - & 3.48 & 12.78 & - & 470 & 147 & 68.62 \\
\hline 0.21 & 23.1 & 33.04 & - & 2.26 & 6.58 & - & 350 & 118 & 66.28 \\
\hline 0.13 & 18.6 & 6.72 & 63.9 & 1.65 & 2.87 & - & 297 & N.D. & $>99.99$ \\
\hline
\end{tabular}

The performance of the PAD system was investigated at three different OLRs for the removal of TKN, TP and O\&G. Table 2 shows the removal efficiencies (Eff) determined under the steady-state conditions of the reactor (the average values of the five sampling dates). The PAD reactor operating at the OLR of $0.13 \mathrm{~kg} \mathrm{VS} /\left(\mathrm{m}^{3} \cdot\right.$ day) was most effective, reducing the content of TKN and O\&G by $64 \%$ and $100 \%$, respectively. The influent O\&G with a concentration of $297 \mathrm{mg} / \mathrm{dm}^{3}$ was completely removed. Decreasing the OLR or decreasing the concentration of the substrate for microorganisms thereby enhances the removal efficiency of TKN and O\&G. The PAD reactor was found to have low efficiency for removing TKN and TP at higher OLRs because TKN removal could not be performed by the anaerobic biological process alone but rather should be coupled with an aerobic biological process or other processes. Under anaerobic conditions, hydrolysis bacteria converted organic nitrogen to ammonia $\left(\mathrm{NH}_{3}\right)$ which is soluble in wastewater at $\mathrm{pH}<7$ and causes high TKN in effluent. However, the phosphorus was a constituent of bacterial cells accumulating in the bottom of the anaerobic digestion tank. Over time, the bacterial cells decomposed simultaneously with the organic matter 
from food wastewater, which resulted in the release of phosphorus into the wastewater under anaerobic conditions [11].

The PAD-FWD system had a high capacity for generating biogas from the food wastewater, and the biogas generated from the system was found to have an upward trend with increasing OLR. At OLRs of $0.42,0.21$ and $0.13 \mathrm{~kg} \mathrm{VS} /\left(\mathrm{m}^{3} \cdot\right.$ day $)$, the amount of biogas generation under steady state was 153,64 and $46 \mathrm{dm}^{3} /$ day, respectively, with a methane concentration ranging between $54.50-62.40 \%$. The biogas generated rate from the system was found to be constant at $0.22-0.27 \mathrm{~m}^{3} / \mathrm{VS}$ removed or $0.53-0.69$ $\mathrm{m}^{3} / \mathrm{kg}$ COD removed at OLRs of $0.42-0.13 \mathrm{~kg} \mathrm{VS} /\left(\mathrm{m}^{3} \cdot\right.$ day $)$. Compared with other studies, the value of biogas per kg of COD removed for the PAD-FWD system was 4 times higher than the anaerobic digestion without mixing within a range of 0.127 $-0.201 \mathrm{~m}^{3} / \mathrm{kg}$ COD removed $[9,10]$. The reason is that the organic substrate in the food wastewater was easily degradable; hence, a high amount of anaerobic microorganisms was able to live and survive in the PAD-FWD system. However, this value is lower than the CSTR (continuous stirred tank reactor) for treating food waste $\left(0.789 \mathrm{~m}^{3} / \mathrm{kg}\right.$ COD removed) [12] because mixing creates a homogeneous substrate and enhances the biodegradation of the feed. The temperature in the PAD-FWD system ranged between 28 and $34{ }^{\circ} \mathrm{C}$. This temperature variation affected the biogas production of the anaerobic microbial because it was able to decompose organic material well when the temperature was over $30^{\circ} \mathrm{C}$. The amount of biogas generation at temperatures higher than $30^{\circ} \mathrm{C}$ was higher than at temperatures below $30^{\circ} \mathrm{C}$ by approximately $15 \%$.

The average $\mathrm{pH}$ of the influent wastewater (pHin) ranged between 6.4-6.6, whereas the $\mathrm{pH}$ of the wastewater and effluent from anaerobic septic tank under steady-state conditions (pHsys, pHeff) ranged between 6.5-6.6 and 6.7-6.9, respectively. When these results were compared with the suitable $\mathrm{pH}$ value for the anaerobic septic tank of 6.6-7.8 [13], the pHsys and pHeff were found to be in a suitable range resulting in good decomposition by the microorganisms in the PAD-FWD system.

Figure 3 shows the VFA and alkalinity of the PAD reactor at various OLRs. It was observed that under steady-state conditions at OLRs of $0.42,0.21$ and $0.13 \mathrm{~kg} \mathrm{VS} /\left(\mathrm{m}^{3} \cdot\right.$ day), the VFA concentration in the effluent decreased to $47.5,23.75$ and $25 \mathrm{mg} / \mathrm{dm}^{3}$, respectively. These values were lower than the suitable VFA values for the anaerobic septic tank of $50-500 \mathrm{mg} / \mathrm{dm}^{3}$ [15]. The decrease in OLR caused the decomposing performance of the microbial to decrease, resulting in an accumulation of VFAsys [14]. The ratio of VFAsys to VFAeff was close to 1 throughout the experiment. It can be noted that fatty acids from the degradation of organic substances during acidogenesis and acetogenesis were efficiently converted into $\mathrm{CH}_{4}$. The trends of Alkin were similar to Alkeff within a range of $267-550 \mathrm{mg} \mathrm{CaCO} / \mathrm{dm}^{3}$ for Alkin and 297-544 mg $\mathrm{CaCO}_{3} / \mathrm{dm}^{3}$ for Alkeff, which was lower than the alkalinity suitable for anaerobic digestion of $1500-2000 \mathrm{mg} \mathrm{CaCO} / \mathrm{dm}^{3}$ [15]. The one important parameter in controlling the anaerobic septic tank to reach a steady state condition was the VFA/Alk ratio. With a VFA/Alk ratio below 0.4 , the anaerobic digestion was a high-buffer system whereby 
it is difficult to change the $\mathrm{pH}$. On the contrary, a VFA/Alk ratio higher than 0.8 caused the $\mathrm{pH}$ of the system to rapidly decrease, thereby causing system instability and failure [16]. In this research, the VFA/Alk ratios of the effluent were below 0.1 at every OLR. These data indicate that the PAD-FWD reactor was suitable for producing biogas.

\subsection{EFFECTS OF LAS SURFACTANT ON PAD-FWD REACTOR PERFORMANCE}

Figure 4 shows the effect of the LAS surfactant on the COD removal efficiency of the PAD-FWD reactor operating at an OLR of $0.13 \mathrm{~kg} \mathrm{VS} /\left(\mathrm{m}^{3} \cdot\right.$ day $)$. The CODsys and CODeff increased when the LAS concentration of $63.4 \mathrm{mg} / \mathrm{dm}^{3}$ was added to the food waste feed, and after 22 days of operation the reactor could reach steady state. The results showed that at the steady state, the CODsys concentration was $523 \mathrm{mg} / \mathrm{dm}^{3}$, which is $20 \%$ higher than that of CODsys without adding LAS, resulting in a decrease in CODsys removal efficiency to $87 \%$. When the LAS concentration was increased to $252 \mathrm{mg} / \mathrm{dm}^{3}$, the reactor failed. Delforno et al. [20] and Sanz et al. [21] concluded that feeding LAS at $14 \mathrm{mg} / \mathrm{dm}^{3}$ resulted in the COD removal efficiency of the anaerobic system increasing from $83 \%$ to $97 \%$, whereas for the LAS feed of $252 \mathrm{mg} / \mathrm{dm}^{3}$ the COD removal efficiency tended to continuously decrease until the system was unable to reach steady state because the LAS could destroy the cell membranes of the anaerobic microbes to affect the sludge flocculation with unusual structures resulting in the leaching of microorganisms from the sludge surface to the effluent and a decrease in efficiency.

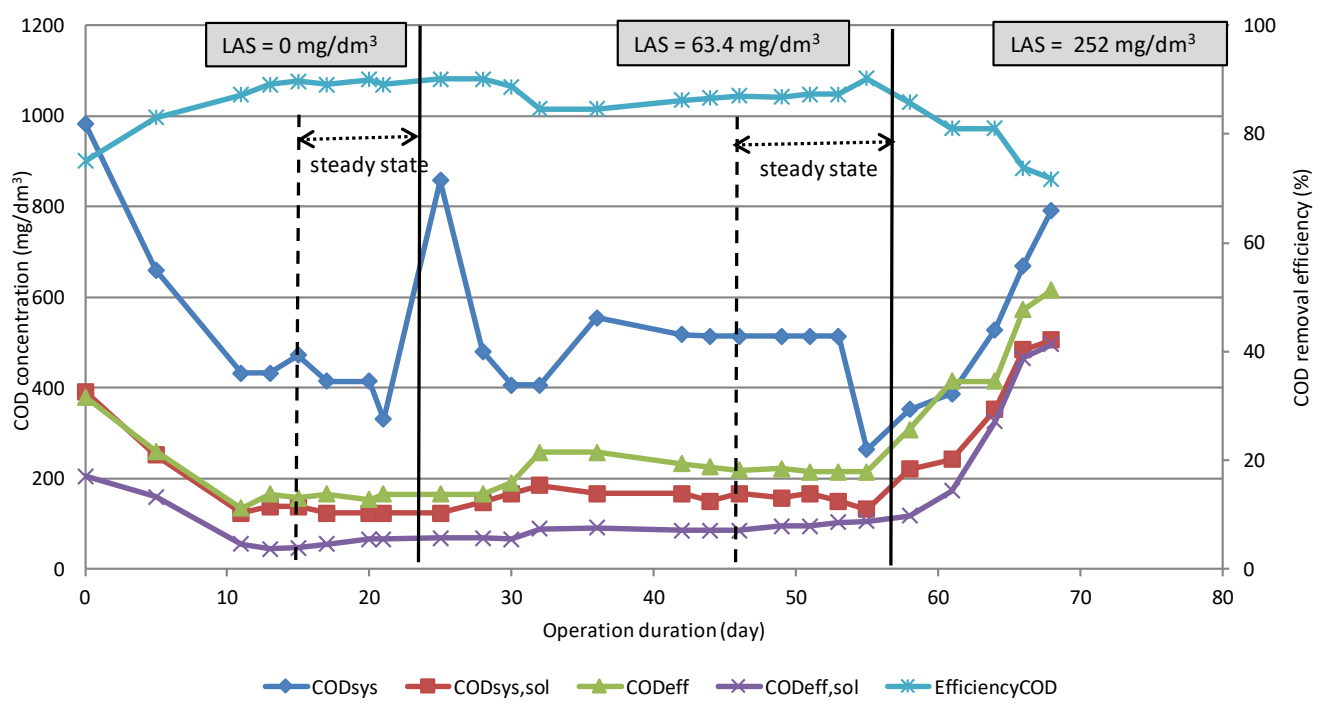

Fig. 4. COD concentration and COD removal efficiency of PAD-FWD system at an OLR of $0.13 \mathrm{~kg} \mathrm{VS} /\left(\mathrm{m}^{3} \cdot\right.$ day $)$ with an added LAS surfactant 
Figure 5 shows that the TSeff of the food waste with the LAS concentration of 63.4 $\mathrm{mg} / \mathrm{dm}^{3}$ was lower than that of food waste alone. The aforementioned findings indicate that TSeff tended to decrease slightly with added LAS surfactant because the LAS surfactant can capture the suspension solids settling at the bottom of the PAD reactor, thereby decreasing the total solids in the effluent and increasing the total solid removal efficiency [22]. However, when the LAS concentration was rapidly increased from 0 to $252 \mathrm{mg} / \mathrm{dm}^{3}$, the VSeff tended to increase until the system was unable to reach steady state. This phenomenon likely occurred because the LAS concentration rapidly increased until the microorganisms in the system were unable to adapt to withstand the conditions, thereby resulting in the restructuring of sludge by finding the sludge leaching out from the system.

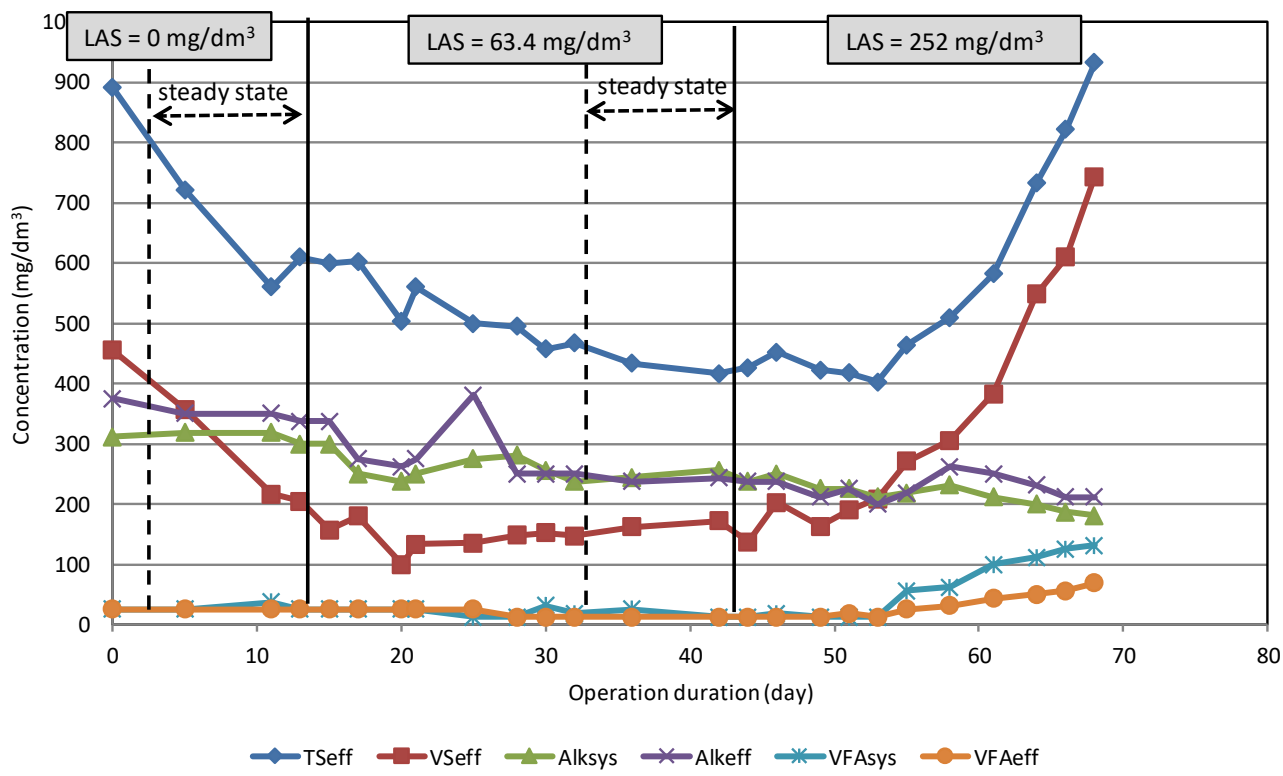

Fig. 5. TS, VS, VFA and Alk of PAD-FWD system at an OLR of $0.13 \mathrm{~kg} \mathrm{VS} /\left(\mathrm{m}^{3} \cdot\right.$ day $)$ with an added LAS surfactant

The PAD reactor could remove LAS from food wastewater with a removal efficiency of $91.64 \%$ and $78.97 \%$ at LAS concentrations of 63.4 and $252 \mathrm{mg} / \mathrm{dm}^{3}$, respectively. Furthermore, the average LAS concentration values in the effluent were 5.3 and $53 \mathrm{mg} / \mathrm{dm}^{3}$, respectively. Compared with the research of Dagoberto et al. [23] using a UASB system to remove LAS with a removal efficiency of approximately $76 \%$, the PAD system had a high performance in decomposing LAS. Increasing the LAS concentration from 0 to 63.4 and $252 \mathrm{mg} / \mathrm{dm}^{3}$ reduced the pHsys and pHeff from $6.5-6.6$ to 6.0-6.5 and 5.5-6.1, and 6.84-6.92, 6.41-6.95 and 5.42-6.21, respectively. The pHsys 
was found to be slightly lower than the suitable $\mathrm{pH}$ for anaerobic microbes with a range of 6.6-7.8 [13].

At the LAS concentration of $63.4 \mathrm{mg} / \mathrm{dm}^{3}$, the VFAsys and VFAeff ranged between 12.0-37.5 and $12.5-25.0 \mathrm{mg} / \mathrm{dm}^{3}$ as acetic acid, respectively (Fig. 5). Compared with not adding LAS, the VFA value was slightly lower. Furthermore, when the LAS concentration was increased to $252 \mathrm{mg} / \mathrm{dm}^{3}$, the VFAsys and VFAeff tended to rapidly increase and accumulated in the system, thereby causing the $\mathrm{pH}$ of the system to decrease while increasing the VFA/Alk ratio to 0.7 and resulting in system failure. The Alksys tended to decrease with increasing LAS concentrations and resulted in the loss of the system buffer. At the LAS concentration of $63.4 \mathrm{mg} / \mathrm{dm}^{3}$, the VFA/Alk ratio of the effluent was 0.1 , which meet the suitable criteria for anaerobic bacteria and biogas generation.

\subsection{EFFECTS OF LAS SURFACTANT ON BIOGAS PRODUCTION RATE}

The LAS surfactant could reduce the biogas generation of the PAD-FWD reactor. Under steady state conditions, at LAS concentrations of 0 and $63.4 \mathrm{mg} / \mathrm{dm}^{3}$, the amounts of biogas generation were 46.2 and $34.1 \mathrm{dm}^{3} /$ day, respectively. The aforementioned findings indicate that the biogas generation tended to decrease with the addition of LAS in the PAD-FWD reactor. At the LAS concentration of $63.4 \mathrm{mg} / \mathrm{dm}^{3}$, the biogas production from PAD-FWD reactor was lower than that without the added LAS at approximately $26 \%$, and the methane concentration was also reduced by approximately $3.5 \%$. This experimental result agreed with the findings of Lee et al. [24] who showed that adding a high amount of LAS surfactant to the anaerobic system could reduce the biogas generation because the surfactant causes the cell membranes of the microorganisms to deteriorate. Degoberto et al. [23] reported that a low amount of LAS surfactant in the anaerobic system was unable to affect the biogas generation, whereas a high amount of LAS could make the system fail because LAS, an anionic detergent compound, can inhibit the growth of archaea bacteria, a group of microbes producing methane, eventually resulting in a cessation of methane generation.

\subsection{OPTIMAL CONDITIONS FOR THE PAD-FWD SYSTEM}

After food wastewater was treated by the PAD-FWD system inside the households, the effluent could be directly released to the environment or discharged through a central wastewater treatment plant. Thus, to define the optimal OLR for the PAD-FWD system, the quality of the effluent at each $\operatorname{OLR}\left(0.42,0.21,0.13 \mathrm{~kg} \mathrm{VS} /\left(\mathrm{m}^{3} \cdot\right.\right.$ day $\left.)\right)$ was compared with the effluent standards for households [18]. Table 3 shows that the effluent quality under each OLR could not meet the effluent standards. However, at an OLR of $0.13 \mathrm{~kg}$ $\mathrm{VS} /\left(\mathrm{m}^{3} \cdot\right.$ day $)$ and HRT of 12 days, the amount of O\&G and TKN of the effluent had the lowest value and met the effluent standards, but the BOD and SS were slightly higher 
than the effluent standards. These data are consistent with the organic treatment efficiency of general anaerobic digestion systems in which the quality of the effluent frequently fails to meet effluent standards for households [18].

Table 3

The characteristics of the sludge and effluent from the PAD-FWD system at various OLR

\begin{tabular}{|c|c|c|c|c|c|c|c|c|c|}
\hline \multirow{4}{*}{ Parameter } & $\begin{array}{r}\text { Star } \\
(\mathrm{HRT}=\end{array}$ & $\begin{array}{l}\text { up } \\
5 \text { days) }\end{array}$ & & $\begin{array}{r}\text { Operat } \\
\text { IRT }=12\end{array}$ & $\begin{array}{l}\text { on } \\
\text { days) }\end{array}$ & & $\begin{array}{c}\text { Fertilizer } \\
\text { std [17] }\end{array}$ & \multirow{4}{*}{$\begin{array}{c}\text { Eff std } \\
{[20]}\end{array}$} & \multirow{4}{*}{$\begin{array}{c}\text { Inf.ww quality } \\
{[27]}\end{array}$} \\
\hline & \multicolumn{6}{|c|}{ OLR $(\mathrm{kg}$ VS/(m³ day $))$} & & & \\
\hline & \multicolumn{2}{|c|}{0.42} & \multicolumn{2}{|c|}{0.42} & 0.21 & 0.13 & & & \\
\hline & Sludge & Eff. & Sludge & Eff. & Eff. & Eff. & & & \\
\hline $\mathrm{OM}, \%$ & 1.32 & 0 & 1.48 & 0.01 & - & - & $>30$ & & \\
\hline $\mathrm{C} / \mathrm{N}$ ratio & $3.0: 1$ & 0 & $8.7: 1$ & $0.14: 1$ & - & - & $<20: 1$ & & \\
\hline $\mathrm{EC}, \mathrm{dS} / \mathrm{m}$ & 2.26 & 3.42 & 2.26 & 1.44 & 1.15 & 0.87 & $<6$ & & \\
\hline $\mathrm{N}, \%$ & 0.44 & N.D. & $<0.50$ & $<0.50$ & - & - & $>1.0$ & & \\
\hline $\mathrm{P}, \%$ & N.D. & N.D. & N.D. & N.D. & - & - & $>0.5$ & & \\
\hline $\mathrm{K}, \%$ & N.D. & N.D. & N.D. & N.D. & - & - & $>0.5$ & & \\
\hline $\mathrm{pH}$ & 6.8 & 7.05 & 6.8 & 6.71 & 6.8 & 6.9 & $5.5-8.5$ & & \\
\hline GI, \% & 7.78 & 18.61 & 13.07 & 52.27 & 70.37 & 104 & $>80$ & & \\
\hline $\mathrm{BOD}, \mathrm{mg} \mathrm{O}_{2} / \mathrm{dm}^{3}$ & - & - & - & 204 & 192 & 32 & & $<20$ & $27-56$ \\
\hline $\mathrm{SS}, \mathrm{mg} / \mathrm{dm}^{3}$ & - & - & - & 462 & 128 & 65 & & $<30$ & $32-99$ \\
\hline $\mathrm{O} \& \mathrm{G}, \mathrm{mg} / \mathrm{dm}^{3}$ & - & - & - & 147 & 118 & N.D. & & $<20$ & \\
\hline $\mathrm{TKN}, \mathrm{mg} / \mathrm{dm}^{3}$ & - & - & - & 66.6 & 33.04 & 6.72 & & $<35$ & $8-15$ \\
\hline $\mathrm{P}, \mathrm{mg} / \mathrm{dm}^{3}$ & & & & 12.78 & 6.58 & 2.87 & & & $0.5-2$ \\
\hline
\end{tabular}

Eff std - the effluent standard of housing estate more than 500 units. Inf.ww quality - the quality of influent wastewater of central wastewater treatment plant.

Moreover, to ensure that the pollutants in the effluent from the PAD-FWD system did not increase the overall burden on the wastewater treatment plant, the quality of the effluent was compared with the properties of influent wastewater of the central wastewater treatment plant as shown in Table 3 [25]. Table 3 shows that the quality of the effluent at an OLR of $0.13 \mathrm{~kg} \mathrm{VS} /\left(\mathrm{m}^{3}\right.$. day) was in the range of the influent properties of the central wastewater treatment plant. In view of the utilization of the effluent and sludge for fertilizer, the bio-sludge from the reactor was sampled to determine the fertilizer properties as shown in Table 3. It was shown that the bio-sludge from the reactor contained less organic matter and the nutrients $(\mathrm{N}, \mathrm{P}, \mathrm{K})$ than fertilizer standards [17]. In other words, the bio-sludge from the reactor was not a sufficient nutrient source for growing plants. The result from the germination index (GI) analysis of the effluent from the digestion tank was 52,70 and $104 \%$ at the OLRs of $0.42,0.21$ and $0.13 \mathrm{~kg}$ $\mathrm{VS} /\left(\mathrm{m}^{3} \cdot\right.$ day $)$, respectively. The aforementioned data indicate that the effluent from the PAD-FWD reactor increased the GI values with decreasing OLR. It was noted that the GI of the effluent at an OLR of $0.13 \mathrm{~kg} \mathrm{VS} /\left(\mathrm{m}^{3}\right.$. day) could meet the fertilizer standard [17]. 
The LAS concentration of $63.4 \mathrm{mg} / \mathrm{dm}^{3}$ was found to be suitable because the PAD-FWD system was able to reach a steady-state condition and its performance was similar to the system without added LAS. This optimal LAS concentration was approximately two times higher than the LAS concentrations of actual wastewater of $30 \mathrm{mg} / \mathrm{dm}^{3}$.

Table 4

Optimal volume of the precast anaerobic digestion tank

\begin{tabular}{|c|c|c|}
\hline $\begin{array}{c}\text { Precast anaerobic } \\
\text { digestion tank size } \\
{\left[\mathrm{dm}^{3}\right]}\end{array}$ & $\begin{array}{c}\text { Food wastewater } \\
\text { loading capacity } \\
{\left[\mathrm{dm}^{3} / \text { day }\right]}\end{array}$ & $\begin{array}{c}\text { Food waste } \\
\text { loading capacity } \\
{[\mathrm{kg} / \text { day }]}\end{array}$ \\
\hline 600 & 50 & 0.3 \\
\hline 800 & 67 & 0.4 \\
\hline 1000 & 83 & 0.51 \\
\hline 1200 & 100 & 0.61 \\
\hline 1600 & 133 & 0.81 \\
\hline 2000 & 167 & 1.01 \\
\hline
\end{tabular}

Hence, the PAD-FWD system should be capable of effectively operating under actual household conditions. According to the results above, the OLR of $0.13 \mathrm{~kg}$ $\mathrm{VS} /\left(\mathrm{m}^{3} \cdot\right.$ day $)$ and HRT of 12 days were the optimal conditions for the PAD-FWD system, and this condition was used to calculate the optimal size of the precast anaerobic digestion tank available in the market [15] as shown in Table 4. These data could be useful in selecting the optimal volume for the PAD-FWD system.

\section{CONCLUSION}

The performance of precast anaerobic digestion tanks combined with food waste disposer systems (PAD-FWD) has been studied in terms of treating food waste and obtaining information on the design of PAD-FWD systems. The results show that the PAD-FWD system could be applied to treat food waste without any added nutrients or alkaline salts into the system. The average COD removal efficiency at OLRs of 0.42 , 0.21 and $0.13 \mathrm{~kg} \mathrm{VS} /\left(\mathrm{m}^{3} \cdot\right.$ day $)$ and at an HRT of 12 days were 86,87 and $89 \%$, respectively. Furthermore, the biogas generation was 153, 64 and $46 \mathrm{dm}^{3} /$ day, respectively. For the LAS surfactant effects, the PAD-FWD system was able to tolerate LAS concentrations of up to $63.4 \mathrm{mg} / \mathrm{dm}^{3}$ with a COD removal efficiency of $87 \%$ and $34 \mathrm{dm}^{3} / \mathrm{day}$ of biogas generation, a reduction of approximately $26 \%$ in comparison with the systems without added LAS. Considering the use of the effluent and sludge for fertilizer, the bio-sludge from the reactor was not a sufficient nutrient source for the growing plants. The results from the germination index (GI) analysis of the effluent from the digestion tank were 52, 70 and $104 \%$ at the OLRs of $0.42,0.21$ and $0.13 \mathrm{~kg} \mathrm{VS} /\left(\mathrm{m}^{3} \cdot\right.$ day $)$, respectively. The GI of the 
effluent at an OLR of $0.13 \mathrm{~kg} \mathrm{VS} /\left(\mathrm{m}^{3}\right.$. day) could meet the fertilizer standard. The effluent quality from the PAD-FWD system at each OLR condition could not meet the effluent standards from households [18]. Hence, this effluent should be collected for treatment in a secondary wastewater treatment plant before being released into public water resources. The quality of the effluent at OLR of $0.13 \mathrm{~kg} \mathrm{VS} /\left(\mathrm{m}^{3} \cdot\right.$ day $)$ was in the range of the influent properties of the central wastewater treatment plant. These data implied that the pollutants in the effluent do not increase the overall burden on the wastewater treatment plant.

\section{ACKNOWLEDGMENTS}

This research was funded by the Ratchadapisek Sompoch Endowment Fund (2016), Chulalongkorn University (CU-59-002-IC). The researchers would like to acknowledge all supports from National Metal and Materials Technology Center (MTEC) and Micro Biotec Co., Ltd. to complete this work.

\section{REFERENCES}

[1] Pollution Control Department of Thailand, Report of Thailand pollution, Bangkok 2004.

[2] Ray N.H.S., Mohanty M.K., Mohanty R.C., Anaerobic digestion of kitchen wastes. Biogas production and pretreatment of wastes. A Review, IJSRP J., 2013, 3 (11), 1.

[3] Velmurugan B., Ramanujam A.R., Anaerobic digestion of vegetable wastes for biogas production in a fed-batch reactor, Int. J. Emerg. Sci., 2011, 1 (3), 478.

[4] ABDUlKarim B.I., ABDUllahi M. E., Effect of buffer $\left(\mathrm{NaHCO}_{3}\right)$ and waste type in high solid thermophilic anaerobic digestion, Int. J. Chem. Tech. Res., 2010, 2 (2), 980.

[5] Rahmat B., PRIYAdi R., Kuswarini P., Effectiveness of anaerobic digestion on reducing municipal waste, IJSTR J., 2014, 3 (3), 98.

[6] SHPINER R., The effect of domestic garbage grinding on sewage systems and wastewater treatment plants, The Technion, Israel Institute of Technology, Haifa 1997.

[7] APHA, AWWA, WPCF, American Public Health Association, American Water Works Association and Water Pollution Control Federation, Standard methods for the examination of water and wastewater, New York 2005.

[8] Agricultural Production Science Research and Development Division, Department of Agriculture, The guidelines for the analysis of organic fertilizer, Bangkok 2008.

[9] ACHARAPORN W., Anaerobic treatment and biogas production of tuna-processing wastewater by using a conventional anaerobic digester, Mahidol University, Bangkok 2003.

[10] PARINYA Y., Noodle-soup wastewater treatment and biogas production by a conventional anaerobic digester, Mahidol University, Bangkok 2005.

[11] CHAISRI S., THANIY A K., Final report of the study of the feces treatment efficiency by anaerobic digestion tank with sludge drying: Songkhala, Songkhala University, 2002.

[12] Somjintana L., Poonyawee P., AnURaK P., The biogas generation from food waste combined with glycerol from biodiesel production process, KKU Eng. J., 2011, 38 (2), 102.

[13] GRAY N.F., Biology of wastewater treatment, Oxford University, New York 1989.

[14] Tiwari M.K., GuHa S., HARENDRANATH C.S., TRIPATHI S., Influence of extrinsic factors on granulation in UASB reactor, Appl. Microbiol. Biotechnol., 2006, 71 (2), 145.

[15] THONGCHAi P., Municipal wastewater and problem in Bangkok and perimeter, National Environment Board, Ministry of Science, Technology and Energy, Bangkok 1987. 
[16] Wastewater Engineering: Treatment, Disposal and Reuse, 4th Ed., Metcalf \& Eddy, Inc., McGraw-Hill, New York 2003.

[17] Department of Agriculture, The Ministry of Agriculture and Cooperatives of Thailand, The standard of organic fertilizer, Bangkok 2005.

[18] Pollution Control Department, The Ministry of Natural Resources and Environment of Thailand, The effluent standard of housing estate, Bangkok 2005.

[19] Mansin T., Industrial Wastewater Treatment Technology, Chulalongkorn University, Bangkok 1999.

[20] Delforno T.P., Okada D.Y., Polizel J., Sakamoto I.K., Vareshe M.B., Microbial characterization and removal of anionic surfactant in an expanded granular sludge bed reactor, Biores. Techn., 2012, $107,103$.

[21] Sanz J.L., Culubret E., De Ferrer J., Moreno A., Berna J.L., Anaerobic biodegradation of linear alkylbenzene sulfonate (LAS) in up-flow anaerobic sludge blanket (UASB) reactors, Biodegradation, 2003, 14 (1), 57.

[22] Kawamura S., Integrated Design and Operation of Water Treatment Facilities, Wiley, New York 2000.

[23] Okada D.Y., Delforno T.P., Esteves A.S., Polizel J., Hirasawa J.S., Duarte I.C.S., Varesche M.B.A., Influence of volatile fatty acid concentration stability on anaerobic degradation of linear alkylbenzene sulfonate, J. Environ. Manage., 2013, 128, 169.

[24] Lee K.H., PARK K.Y., Khanal S.K., LeE W., Effects of household on anaerobic fermentation of kitchen wastewater from food waste disposer, J. Hazard. Mater., 2013, 244, 39.

[25] Nantamol L., ChanathiP P., The resource efficiency of Centralized Municipal Wastewater in Bang$k o k$, 1st Conference on Environmental Science, Engineering and Management, Chulalongkorn University, 2009. 